\title{
Phases in the subsolidus area of the system $\mathrm{CuO}-\mathrm{V}_{2} \mathrm{O}_{5}-\mathrm{Fe}_{2} \mathrm{O}_{3}$
}

\author{
Anna Blonska-Tabero
}

Bretsznajder Special Chapter

(C) The Author(s) 2012. This article is published with open access at Springerlink.com

\begin{abstract}
The phase equilibria in the solid state in the system $\mathrm{FeVO}_{4}-\mathrm{Cu}_{3} \mathrm{~V}_{2} \mathrm{O}_{8}$ and $\mathrm{FeVO}_{4}-\mathrm{CuO}$ have been determined. Based on the obtained DTA and XRD analysis results and some additional research, a phase diagram in the whole subsolidus area of the system $\mathrm{CuO}-\mathrm{V}_{2} \mathrm{O}_{5}-\mathrm{Fe}_{2} \mathrm{O}_{3}$ has been worked out. Eighteen subsidiary subsystems can be distinguished in this ternary system. Basic properties of the obtained phases with howardevansite- and lyonsite-type structure have been investigated by DTA, IR, and SEM methods.
\end{abstract}

Keywords System $\mathrm{CuO}-\mathrm{V}_{2} \mathrm{O}_{5}-\mathrm{Fe}_{2} \mathrm{O}_{3} \cdot \mathrm{DTA} \cdot \mathrm{XRD} \cdot$ IR · Solid-state reactions

\section{Introduction}

It is known that the components of the ternary systems $\mathrm{MO}-\mathrm{V}_{2} \mathrm{O}_{5}-\mathrm{Fe}_{2} \mathrm{O}_{3}$ as well as the compounds existing in their lateral systems catalyze a lot of chemical reactions [1-3]. Therefore, it can be expected that new phases forming with an involvement of all components of such systems will be active in catalytic processes, too. Searching for these new potential catalysts is very often conducted through the investigation of phase relations in subsolidus areas of the multicomponent oxide systems. Such studies enable to establish the composition of the new compounds, while in the case of phases with variable composition allow to determine the range of their homogeneity. Taking into consideration the possibility of application of the obtained

\footnotetext{
A. Blonska-Tabero ( $\square)$

Department of Inorganic and Analytical Chemistry,

West Pomeranian University of Technology, Al. Piastow 42,

71-065 Szczecin, Poland

e-mail: abtab@zut.edu.pl
}

phases, very important is the knowledge of the range of their coexistence with the other compounds formed in a given multicomponent system.

Compounds forming in the lateral systems of the ternary system $\mathrm{CuO}-\mathrm{V}_{2} \mathrm{O}_{5}-\mathrm{Fe}_{2} \mathrm{O}_{3}$ as well as their properties are known [4-6]. Recently, as a result of the research on phase relations in the limited concentration range of the components of this ternary system, unknown till now compound with the formula $\mathrm{Cu}_{13} \mathrm{Fe}_{4} \mathrm{~V}_{10} \mathrm{O}_{44}$ has been obtained [7]. This compound crystallizes in the monoclinic system and melts incongruently at $790 \pm 5{ }^{\circ} \mathrm{C}$ [7]. In the system $\mathrm{CuO}-\mathrm{V}_{2} \mathrm{O}_{5}-$ $\mathrm{Fe}_{2} \mathrm{O}_{3}$ also are formed another two phases: one with howardevansite-type structure and the other with lyonsitetype structure. Lyonsite is a mineral with the formula $\alpha-\mathrm{Cu}_{3} \mathrm{Fe}_{4} \mathrm{~V}_{6} \mathrm{O}_{24}$, which was discovered in the summit crater fumarole of the Izalco volcano (El Salvador) [8]. This vanadate, when synthesized in the laboratory by the conventional method of sintering or by the method of coprecipitation, crystallizes in a different form that is as $\beta-\mathrm{Cu}_{3} \mathrm{Fe}_{4} \mathrm{~V}_{6} \mathrm{O}_{24}$ with a structure closely related to mineral howardevansite, i.e., $\mathrm{NaCuFe}_{2} \mathrm{~V}_{3} \mathrm{O}_{12}$ [9-12]. However, the other authors [13] did not obtained $\beta-\mathrm{Cu}_{3} \mathrm{Fe}_{4} \mathrm{~V}_{6} \mathrm{O}_{24}$. They have obtained the howardevansite-type phase as well as the lyonsite-type phase, but the composition of both phases differs from that corresponding to the formula $\mathrm{Cu}_{3} \mathrm{Fe}_{4} \mathrm{~V}_{6} \mathrm{O}_{24}$. Moreover, both phases have ranges of homogeneity as expressed by $\mathrm{Cu}_{3+1.5 x} \mathrm{Fe}_{4-x} \mathrm{~V}_{6} \mathrm{O}_{24}(-0.333 \leq x \leq-0.167$ for howardevansite-type phase and $0.667 \leq x<0.778$ for lyonsite-type phase) [13].

It is known from the literature data that phases with the lyonsite-type structure catalyze oxidative dehydrogenation of propane [14]. Investigation of phase formation in the system $\mathrm{CuO}-\mathrm{V}_{2} \mathrm{O}_{5}-\mathrm{Fe}_{2} \mathrm{O}_{3}$ and their properties are therefore interesting not only because of the cognitive value of the obtained results, but also from the catalytic point of view. 
The objective of this study was to conduct the verifying study relating to formation of the howardevansite- and the lyonsite-type phase as well as to investigate the phase equilibria establishing in the whole subsolidus area of the system $\mathrm{CuO}-\mathrm{V}_{2} \mathrm{O}_{5}-\mathrm{Fe}_{2} \mathrm{O}_{3}$. Furthermore characterization of basic properties of the obtained phases has been presented.

\section{Experimental}

For the experiments the following were used: $\mathrm{CuO}$ (p.a., Fluka), $\mathrm{V}_{2} \mathrm{O}_{5}$ (p.a., Riedel-de $\mathrm{Haën}$ ), $\alpha-\mathrm{Fe}_{2} \mathrm{O}_{3}$ (p.a., $\mathrm{POCh}$ ) and vanadates, $\mathrm{FeVO}_{4}$ and $\mathrm{Fe}_{2} \mathrm{~V}_{4} \mathrm{O}_{13}$, obtained by the procedures given in the studies $[4,15]$.

The syntheses were carried out by the standard solid-state reaction method [16-20]. The reagents in suitable weighed portions were homogenized by grinding in a mechanical agate mortar and then they were calcined in air atmosphere for several stages. On completion of each heating stage the samples were cooled down in furnace to room temperature and, after grinding, they were examined by XRD method, whereas some selected samples by the DTA as well. The heating temperatures of the samples were chosen based on their DTA curves to avoid their melting. The melting temperatures of the samples were determined as the onset temperature of the first endothermic effect recorded in their DTA curves. Samples, whose composition did not change after two consecutive heating stages, were considered to be at equilibrium.

Differential thermal analyses were performed using the Paulik-Paulik-Erdey type derivatograph (MOM, Hungary). Conditions of the measurements were the following: air atmosphere, mass of each sample $500 \mathrm{mg}$, heating rate $10{ }^{\circ} \mathrm{C} \mathrm{min}{ }^{-1}$, quartz crucibles, $\mathrm{Al}_{2} \mathrm{O}_{3}$ as reference material, temperature range $20-1,000{ }^{\circ} \mathrm{C}$.

The phase composition of the samples was checked by XRD method using a diffractometer HZG-4/A2 (Carl Zeiss, Germany) with $\mathrm{Cu}-\mathrm{K}_{\alpha} / \mathrm{Ni}$ radiation. The identification of phases occurring in the samples was conducted based on their XRD characteristics contained in the PDF cards and in the study [7].

The IR spectra were obtained with the use of an IR Specord M80 spectrometer (Carl Zeiss Jena, Germany), by applying the technique of pressing pastilles of the investigated sample together with $\mathrm{KBr}$ in a ratio $1: 300$ by weight.

The morphology as well as the size of the crystals was observed by means of scanning electron microscope (JSM1600, Jeol, Japan).

\section{Results and discussion}

Phase formation in the system $\mathrm{FeVO}_{4}-\mathrm{Cu}_{3} \mathrm{~V}_{2} \mathrm{O}_{8}$

The research was begun with the investigations of phase relations in one of cross-sections of the $\mathrm{CuO}-\mathrm{V}_{2} \mathrm{O}_{5}-\mathrm{Fe}_{2} \mathrm{O}_{3}$ system, i.e., in the system $\mathrm{FeVO}_{4}-\mathrm{Cu}_{3} \mathrm{~V}_{2} \mathrm{O}_{8}$. These investigations included verifying study relating to the howardevansite-type phase (hereafter H-type phase) as well as the lyonsite-type phase (hereafter L-type phase) forming in this system. Seventeen mixtures of oxides (Table 1) were prepared and then heated in the following stages: $560{ }^{\circ} \mathrm{C}(20 \mathrm{~h})+600{ }^{\circ} \mathrm{C}(20 \mathrm{~h})+670{ }^{\circ} \mathrm{C}(20 \mathrm{~h}) \times 2$. The final heating stage of all the samples was performed at $670{ }^{\circ} \mathrm{C}$, according to the temperature of syntheses carried out by authors [13]. The composition of the initial mixtures, their composition expressed as $\mathrm{Cu}_{3+1.5 x} \mathrm{Fe}_{4-x} \mathrm{~V}_{6} \mathrm{O}_{24}$ (the formula proposed in [13]), and XRD analysis results for all the samples after their final heating stage are presented in Table 1. Samples marked with asterisk have the compositions corresponding to the samples investigated by Belik et al. [13]. Based on the obtained results the existence of two subsidiary subsystems in the $\mathrm{CuO}-\mathrm{V}_{2} \mathrm{O}_{5}-\mathrm{Fe}_{2} \mathrm{O}_{3}$ system was stated. In both of them the new compound $\mathrm{Cu}_{13} \mathrm{Fe}_{4} \mathrm{~V}_{10} \mathrm{O}_{44}$ [7] occurs. This compound was unknown earlier, therefore in the samples 12-15 described by Belik et al. [13], apart from $\mathrm{Cu}_{2} \mathrm{~V}_{2} \mathrm{O}_{7}$ and L-type phase, the presence of an unidentified phase was reported. The data presented in Table 1 indicate furthermore that the H-type phase has the homogeneity range with the formula $\mathrm{Cu}_{3+1.5 x} \mathrm{Fe}_{4-x} \mathrm{~V}_{6} \mathrm{O}_{24} \quad(-0.5<x<0.041)$, whereas the homogeneity range of the L-type phase can be described as $\mathrm{Cu}_{3+1.5 x} \mathrm{Fe}_{4-x} \mathrm{~V}_{6} \mathrm{O}_{24} \quad(0.551<x<0.778)$. These ranges are bigger with comparison to those given by Belik et al. [13]. The synthesis of $\beta-\mathrm{Cu}_{3} \mathrm{Fe}_{4} \mathrm{~V}_{6} \mathrm{O}_{24}$ was successful (sample 6). The results of XRD analysis, performed after each heating stage of sample 6 , have proved that after any heating stage L-type phase was not identified. For comparison, an interesting fact is that the mechanochemical synthesis of double vanadate $\mathrm{Cu}_{3} \mathrm{Fe}_{4} \mathrm{~V}_{6} \mathrm{O}_{24}$ leads to $\alpha$ $\mathrm{Cu}_{3} \mathrm{Fe}_{4} \mathrm{~V}_{6} \mathrm{O}_{24}$ instead of $\beta-\mathrm{Cu}_{3} \mathrm{Fe}_{4} \mathrm{~V}_{6} \mathrm{O}_{24}$ [11].

Some physicochemical properties of phases forming in the system $\mathrm{FeVO}_{4}-\mathrm{Cu}_{3} \mathrm{~V}_{2} \mathrm{O}_{8}$

The selected obtained phases, i.e., H-type phase (sample 6) as well as L-type phase (sample 11) were subjected to an investigation by infrared spectroscopy method. Figure 1 shows the IR spectra of both phases. IR spectrum of H-type phase (curve a) is very similar to IR spectra of the other phases with such structure [21, 22]. According to the literature data relating to the H-type phase structure [10], the absorption bands recorded in the wave-number range $1,070-540 \mathrm{~cm}^{-1}$ can be most likely ascribed to stretching vibrations of the $\mathrm{V}-\mathrm{O}$ bonds in the $\mathrm{VO}_{4}$ tetrahedra [23-25] The absorption bands located in the remaining wavenumber range can be due to the stretching vibrations of $\mathrm{M}$ $\mathrm{O}$ bonds in the $\mathrm{FeO}_{6}, \mathrm{CuO}_{5}$, and $\mathrm{CuO}_{4}$ polyhedra as well as to the bending vibrations of the $\mathrm{O}-\mathrm{V}-\mathrm{O}$ bonds in the $\mathrm{VO}_{4}$ 
Table 1 The system $\mathrm{FeVO}_{4}-\mathrm{Cu}_{3} \mathrm{~V}_{2} \mathrm{O}_{8}$

\begin{tabular}{|c|c|c|c|c|c|}
\hline \multirow[t]{2}{*}{ No. } & \multicolumn{3}{|c|}{ Composition of initial mixtures $/ \mathrm{mol} \%$} & \multirow{2}{*}{$\begin{array}{l}\text { Value of } x \text { in } \\
\text { composition expressed } \\
\text { as } \mathrm{Cu}_{3+1.5 x} \mathrm{Fe}_{4-x} \mathrm{~V}_{6} \mathrm{O}_{24}\end{array}$} & \multirow{2}{*}{$\begin{array}{l}\text { Phases identified after the final } \\
\text { heating stage }\end{array}$} \\
\hline & $\mathrm{CuO}$ & $\mathrm{V}_{2} \mathrm{O}_{5}$ & $\mathrm{Fe}_{2} \mathrm{O}_{3}$ & & \\
\hline 1 & 13.04 & 45.65 & 41.31 & -1.429 & H-type phase, $\mathrm{FeVO}_{4}$ \\
\hline 2 & 23.08 & 42.31 & 34.61 & -0.909 & H-type phase, $\mathrm{FeVO}_{4}$ \\
\hline $3^{\mathrm{a}}$ & 30.00 & 40.00 & 30.00 & -0.500 & H-type phase, $\mathrm{FeVO}_{4}^{\mathrm{b}}$ \\
\hline $4^{\mathrm{a}}$ & 32.61 & 39.13 & 28.26 & -0.333 & H-type phase \\
\hline $5^{\mathrm{a}}$ & 35.11 & 38.30 & 26.59 & -0.167 & H-type phase \\
\hline $6^{\mathrm{a}}$ & 37.50 & 37.50 & 25.00 & 0 & H-type phase $\left(\beta-\mathrm{Cu}_{3} \mathrm{Fe}_{4} \mathrm{~V}_{6} \mathrm{O}_{24}\right)$ \\
\hline 7 & 38.08 & 37.31 & 24.61 & 0.041 & H-type phase, L-type phase ${ }^{b}$ \\
\hline $8^{\mathrm{a}}$ & 42.00 & 36.00 & 22.00 & 0.333 & H-type phase, L-type phase \\
\hline 9 & 44.75 & 35.08 & 20.17 & 0.551 & L-type phase, $\mathrm{H}$-type phase ${ }^{\mathrm{b}}$ \\
\hline $10^{\mathrm{a}}$ & 45.35 & 34.88 & 19.77 & 0.600 & L-type phase \\
\hline $11^{\mathrm{a}}$ & 46.15 & 34.62 & 19.23 & 0.667 & L-type phase \\
\hline $12^{\mathrm{a}}$ & 47.47 & 34.18 & 18.35 & 0.778 & L-type phase, $\mathrm{Cu}_{2} \mathrm{~V}_{2} \mathrm{O}_{7}^{\mathrm{b}}, \mathrm{Cu}_{13} \mathrm{Fe}_{4} \mathrm{~V}_{10} \mathrm{O}_{44}^{\mathrm{b}}$ \\
\hline $13^{\mathrm{a}}$ & 50.00 & 33.33 & 16.67 & 1.000 & L-type phase, $\mathrm{Cu}_{2} \mathrm{~V}_{2} \mathrm{O}_{7}, \mathrm{Cu}_{13} \mathrm{Fe}_{4} \mathrm{~V}_{10} \mathrm{O}_{44}$ \\
\hline $14^{\mathrm{a}}$ & 55.26 & 31.58 & 13.16 & 1.500 & L-type phase, $\mathrm{Cu}_{2} \mathrm{~V}_{2} \mathrm{O}_{7}, \mathrm{Cu}_{13} \mathrm{Fe}_{4} \mathrm{~V}_{10} \mathrm{O}_{44}$ \\
\hline $15^{\mathrm{a}}$ & 60.00 & 30.00 & 10.00 & 2.000 & L-type phase, $\mathrm{Cu}_{2} \mathrm{~V}_{2} \mathrm{O}_{7}, \mathrm{Cu}_{13} \mathrm{Fe}_{4} \mathrm{~V}_{10} \mathrm{O}_{44}$ \\
\hline 16 & 65.63 & 28.12 & 6.25 & 2.667 & $\mathrm{Cu}_{2} \mathrm{~V}_{2} \mathrm{O}_{7}, \mathrm{Cu}_{13} \mathrm{Fe}_{4} \mathrm{~V}_{10} \mathrm{O}_{44}$ \\
\hline 17 & 67.50 & 27.50 & 5.00 & 2.909 & $\mathrm{Cu}_{2} \mathrm{~V}_{2} \mathrm{O}_{7}, \mathrm{Cu}_{13} \mathrm{Fe}_{4} \mathrm{~V}_{10} \mathrm{O}_{44}, \mathrm{Cu}_{3} \mathrm{~V}_{2} \mathrm{O}_{8}$ \\
\hline
\end{tabular}

Composition of the investigated samples and XRD analysis results for samples after their final heating stage

a Samples with compositions corresponding to the samples investigated by Belik et al. [13]

b Small amount

tetrahedra $[25,26]$. The IR spectrum of the L-type phase (curve b) is clearly different from that characteristic for the H-type phase. It contains one very broad absorption band covering the wave-number range of $1,020-360 \mathrm{~cm}^{-1}$. Only in the highest wave-number range one acute band with its maximum at $980 \mathrm{~cm}^{-1}$ is observed. For comparison, Fig. 1 (curve c) shows IR spectrum of another L-type phase with analogous formula, i.e., $\mathrm{Co}_{4} \mathrm{Fe}_{3.333} \mathrm{~V}_{6} \mathrm{O}_{24}$, forming in the system $\mathrm{FeVO}_{4}-\mathrm{Co}_{3} \mathrm{~V}_{2} \mathrm{O}_{8}$ [27]. It can be concluded that a broad absorption band is characteristic for IR spectra of the L-type phases.

Figure 2 presents a scanning electron microscopic image of the H-type phase (sample 6), while Fig. 3 shows a SEM image of the L-type phase (sample 11). The crystals revealed on the images differ much by their morphology as well as by their size. The crystals visible in Fig. 2 resemble the crystals of the other phases with howardevansite-type structure whose SEM images have been shown in an earlier study [21]. They are much differentiated in size. The crystals of the L-type phase (Fig. 3), in comparison with the H-type phase crystals, are much more regular both in shape and in size.

In the next stage of research thermal properties of the both phases were investigated. Figure 4 shows the fragments of DTA curves of the H-type phase (sample 4curve a and sample 6-curve b) as well as of the L-type phase (sample 11 - curve c). On the DTA curves of these

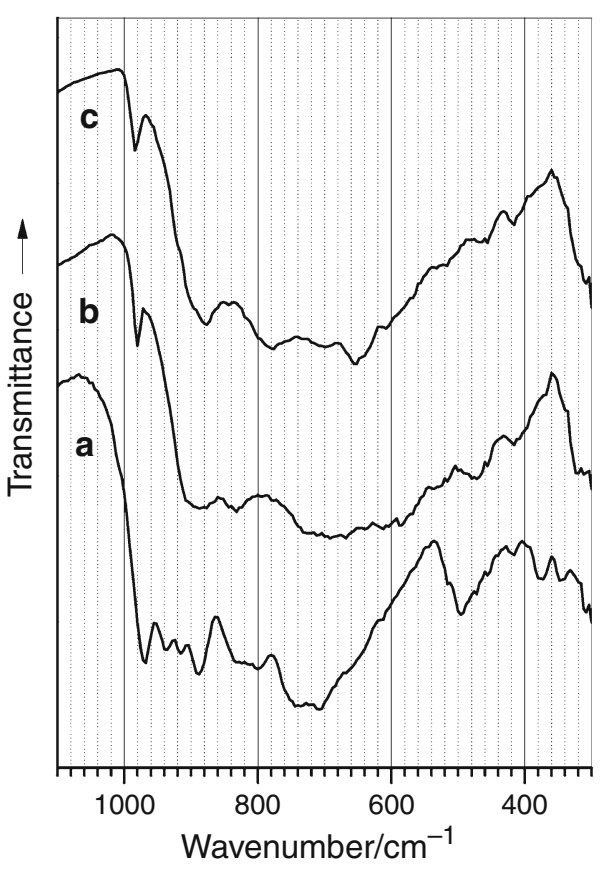

Fig. 1 IR spectra of $a$-H-type phase (sample 6), $b$ L-type phase (sample 11), and $c \mathrm{Co}_{4} \mathrm{Fe}_{3.333} \mathrm{~V}_{6} \mathrm{O}_{24}$

phases two endothermic effects beginning at close temperatures were registered. The onset temperature of the first effect on the DTA curves of the H-type phase depends on the phase composition and is equal to $820 \pm 5^{\circ} \mathrm{C}$ for 


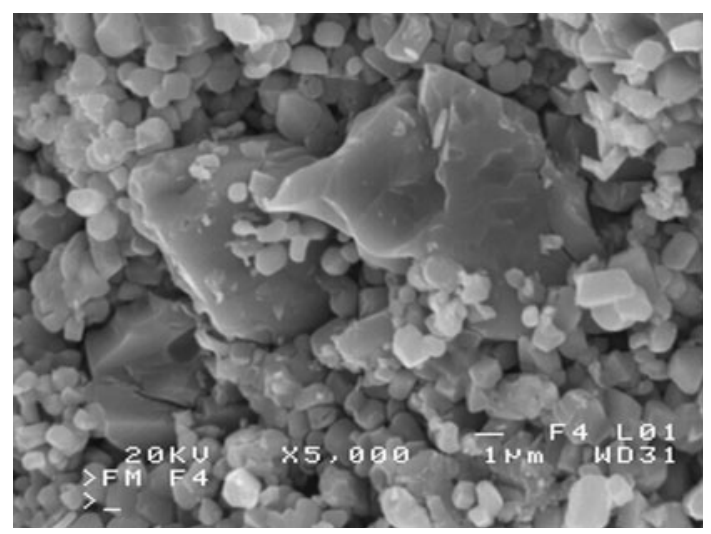

Fig. 2 SEM image of H-type phase (sample 6)

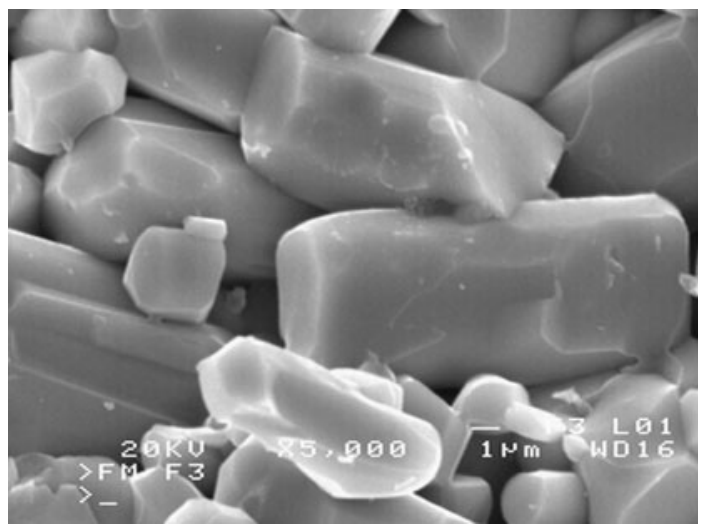

Fig. 3 SEM image of L-type phase (sample 11)
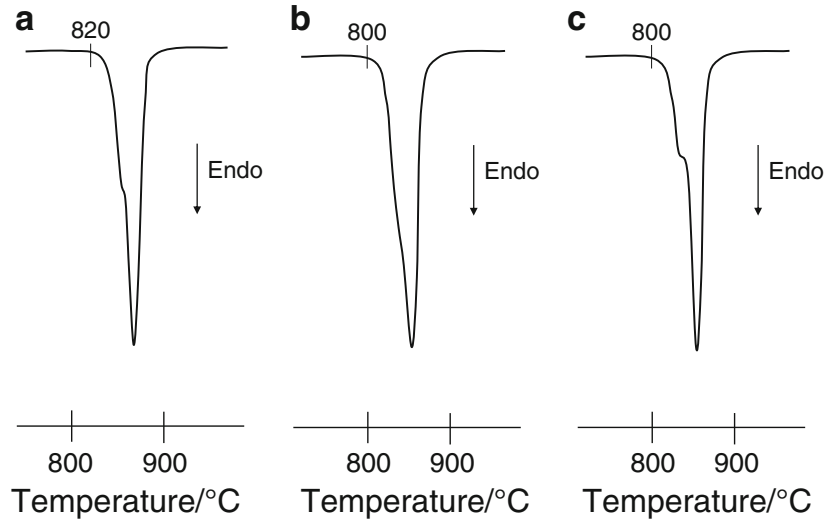

Fig. 4 Fragments of DTA curves of: a H-type phase (sample 4), b H-type phase (sample 6), and c L-type phase (sample 11)

sample 4 and $800 \pm 5{ }^{\circ} \mathrm{C}$ for sample 6 . In the case of the L-type phase, the onset temperatures $\left(800 \pm 5^{\circ} \mathrm{C}\right)$ of the first effects registered on the DTA curves of samples 10 and 11 differ insignificant (differences in the limit of accuracy of reading these temperatures).

To determine the kind of transition beginning at the onset temperatures, samples 6 and 11 were additionally heated at $805{ }^{\circ} \mathrm{C}$ (just after beginning of the effects) and at $820{ }^{\circ} \mathrm{C}$ (i.e., at the temperature corresponding to a half of the height of the first endothermic effects registered on their DTA curves) for $2 \mathrm{~h}$ and then they were rapidly quenched and subjected to XRD study. In both samples, on removal from the furnace at $805^{\circ} \mathrm{C}$ as well as at $820^{\circ} \mathrm{C}$, the liquid was observed. XRD analysis results of the "frozen" samples point to incongruent melting of both phases. The sole solid phase, occurring in the system $\mathrm{CuO}$ $\mathrm{V}_{2} \mathrm{O}_{5}-\mathrm{Fe}_{2} \mathrm{O}_{3}$, identified in the samples after their melting, was $\alpha-\mathrm{Fe}_{2} \mathrm{O}_{3}$ (melting temperature above $1,000{ }^{\circ} \mathrm{C}$ ). However, the course of the DTA curves of both phases indicates that they melt with deposition of the second solid phase with the similar melting point. Due to the closeness of temperatures of these two effects, in the experiment conditions another solid product was not found.

Phase equilibria in the system $\mathrm{FeVO}_{4}-\mathrm{CuO}$

The objective of the next stage of the research was to determine the phase equilibria in the second cross-section of the ternary system $\mathrm{CuO}-\mathrm{V}_{2} \mathrm{O}_{5}-\mathrm{Fe}_{2} \mathrm{O}_{3}$, i.e., in the system $\mathrm{FeVO}_{4}-\mathrm{CuO}$. Eleven mixtures of the oxides were prepared and then heated in the following stages: $560{ }^{\circ} \mathrm{C}$ $(20 \mathrm{~h})+600{ }^{\circ} \mathrm{C}(20 \mathrm{~h})+720^{\circ} \mathrm{C}(20 \mathrm{~h}) \times 2$. The composition of initial mixtures and of the samples after their final heating stage is shown in Table 2. The presented data indicate that the system $\mathrm{FeVO}_{4}-\mathrm{CuO}$ is a cross-section of the system $\mathrm{CuO}-\mathrm{V}_{2} \mathrm{O}_{5}-\mathrm{Fe}_{2} \mathrm{O}_{3}$, going through its eight subsidiary subsystems. Two of them are diphase, whereas the remaining six are triphase.

Table 2 The system $\mathrm{FeVO}_{4}-\mathrm{CuO}$

\begin{tabular}{llrrl}
\hline No. & \multicolumn{3}{l}{$\begin{array}{l}\text { Composition of initial } \\
\text { mixtures/mol\% }\end{array}$} & \\
\cline { 2 - 4 } & $\mathrm{CuO}$ & $\mathrm{V}_{2} \mathrm{O}_{5}$ & $\mathrm{Fe}_{2} \mathrm{O}_{3}$ & \\
\hline 18 & 85.00 & 7.50 & 7.50 & $\mathrm{Cu}_{5} \mathrm{~V}_{2} \mathrm{O}_{10}, \mathrm{CuFe}_{2} \mathrm{O}_{4}, \mathrm{CuO}$ \\
19 & 75.00 & 12.50 & 12.50 & $\mathrm{Cu}_{5} \mathrm{~V}_{2} \mathrm{O}_{10}, \mathrm{CuFe}_{2} \mathrm{O}_{4}$ \\
20 & 73.00 & 13.50 & 13.50 & $\mathrm{Cu}_{5} \mathrm{~V}_{2} \mathrm{O}_{10}, \mathrm{CuFe}_{2} \mathrm{O}_{4}, \mathrm{Fe}_{2} \mathrm{O}_{3}$ \\
21 & 71.42 & 14.29 & 14.29 & $\mathrm{Cu}_{5} \mathrm{~V}_{2} \mathrm{O}_{10}, \mathrm{Fe}_{2} \mathrm{O}_{3}$ \\
22 & 60.00 & 20.00 & 20.00 & $\mathrm{Cu}_{5} \mathrm{~V}_{2} \mathrm{O}_{10}, \mathrm{Fe}_{2} \mathrm{O}_{3}, \mathrm{Cu}_{13} \mathrm{Fe}_{4} \mathrm{~V}_{10} \mathrm{O}_{44}$ \\
23 & 56.52 & 21.74 & 21.74 & $\mathrm{Fe}_{2} \mathrm{O}_{3}, \mathrm{Cu}_{13} \mathrm{Fe}_{4} \mathrm{~V}_{10} \mathrm{O}_{44}$ \\
24 & 50.00 & 25.00 & 25.00 & $\mathrm{Fe}_{2} \mathrm{O}_{3}, \mathrm{Cu}_{13} \mathrm{Fe}_{4} \mathrm{~V}_{10} \mathrm{O}_{44}, \mathrm{~L}$-type phase \\
25 & 39.50 & 30.25 & 30.25 & $\mathrm{Fe}_{2} \mathrm{O}_{3}, \mathrm{~L}$-type phase \\
26 & 37.00 & 31.50 & 31.50 & $\mathrm{Fe}_{2} \mathrm{O}_{3}, \mathrm{~L}$-type phase, $\mathrm{H}$-type phase \\
27 & 31.00 & 34.50 & 34.50 & $\mathrm{Fe}_{2} \mathrm{O}_{3}, \mathrm{H}$-type phase \\
28 & 15.00 & 42.50 & 42.50 & $\mathrm{Fe}_{2} \mathrm{O}_{3}, \mathrm{H}$-type phase, FeVO \\
\hline
\end{tabular}

Composition of initial mixtures and XRD analysis results for samples after their final heating stage 
Table 3 The system $\mathrm{CuO}-\mathrm{V}_{2} \mathrm{O}_{5}-\mathrm{Fe}_{2} \mathrm{O}_{3}$

\begin{tabular}{|c|c|c|c|c|c|}
\hline \multirow[t]{2}{*}{ No. } & \multicolumn{3}{|c|}{ Composition of initial mixtures $/ \mathrm{mol} \%$} & \multirow[t]{2}{*}{ Heating conditions } & \multirow[t]{2}{*}{ Phases at equilibrium } \\
\hline & $\mathrm{CuO}$ & $\mathrm{V}_{2} \mathrm{O}_{5}$ & $\mathrm{Fe}_{2} \mathrm{O}_{3}$ & & \\
\hline 29 & 55.00 & 40.00 & 5.00 & \multirow[t]{2}{*}{$560^{\circ} \mathrm{C}(20 \mathrm{~h})+600{ }^{\circ} \mathrm{C}(20 \mathrm{~h}) \times 2$} & H-type phase, $\mathrm{CuV}_{2} \mathrm{O}_{6}, \mathrm{Cu}_{2} \mathrm{~V}_{2} \mathrm{O}_{7}$ \\
\hline 30 & 43.00 & 45.00 & 12.00 & & $\mathrm{H}$-type phase, $\mathrm{CuV}_{2} \mathrm{O}_{6}$ \\
\hline 31 & 25.00 & 55.00 & 20.00 & \multirow[t]{2}{*}{$560{ }^{\circ} \mathrm{C}(20 \mathrm{~h})+580{ }^{\circ} \mathrm{C}(20 \mathrm{~h}) \times 2$} & $\mathrm{H}$-type phase, $\mathrm{CuV}_{2} \mathrm{O}_{6}, \mathrm{~V}_{2} \mathrm{O}_{5}$ \\
\hline 32 & 32.00 & 61.00 & 7.00 & & H-type phase, $\mathrm{CuV}_{2} \mathrm{O}_{6}, \mathrm{~V}_{2} \mathrm{O}_{5}$ \\
\hline 33 & 15.00 & 50.00 & 35.00 & \multirow[t]{2}{*}{$560{ }^{\circ} \mathrm{C}(20 \mathrm{~h}) \times 3$} & H-type phase, $\mathrm{V}_{2} \mathrm{O}_{5}, \mathrm{FeVO}_{4}$ \\
\hline 34 & 15.00 & 60.00 & 25.00 & & H-type phase, $\mathrm{V}_{2} \mathrm{O}_{5}, \mathrm{FeVO}_{4}$ \\
\hline 35 & 44.00 & 36.00 & 20.00 & \multirow[t]{4}{*}{$560{ }^{\circ} \mathrm{C}(20 \mathrm{~h})+600{ }^{\circ} \mathrm{C}(20 \mathrm{~h})+700{ }^{\circ} \mathrm{C}(20 \mathrm{~h}) \times 2$} & $\mathrm{H}$-type phase, L-type phase, $\mathrm{Cu}_{2} \mathrm{~V}_{2} \mathrm{O}_{7}$ \\
\hline 36 & 72.00 & 24.00 & 4.00 & & $\mathrm{Cu}_{3} \mathrm{~V}_{2} \mathrm{O}_{8}, \mathrm{Cu}_{11} \mathrm{~V}_{6} \mathrm{O}_{26}, \mathrm{Cu}_{13} \mathrm{Fe}_{4} \mathrm{~V}_{10} \mathrm{O}_{44}$ \\
\hline 37 & 55.00 & 34.12 & 10.88 & & L-type phase, $\mathrm{Cu}_{2} \mathrm{~V}_{2} \mathrm{O}_{7}$ \\
\hline 38 & 78.00 & 20.00 & 2.00 & & $\mathrm{Cu}_{11} \mathrm{~V}_{6} \mathrm{O}_{26}, \mathrm{Cu}_{13} \mathrm{Fe}_{4} \mathrm{~V}_{10} \mathrm{O}_{44}, \mathrm{Cu}_{5} \mathrm{~V}_{2} \mathrm{O}_{10}$ \\
\hline
\end{tabular}

Composition of initial mixtures, their heating conditions, and XRD analysis results for samples after the final heating stage

Subsolidus area of the system $\mathrm{CuO}-\mathrm{V}_{2} \mathrm{O}_{5}-\mathrm{Fe}_{2} \mathrm{O}_{3}$

The results obtained till now allowed a dividing of a part of the subsolidus area of the ternary system $\mathrm{CuO}-\mathrm{V}_{2} \mathrm{O}_{5^{-}}$ $\mathrm{Fe}_{2} \mathrm{O}_{3}$ into ten subsidiary subsystems. This division did not embrace the polygons labelled by the phases: $\left(\mathrm{Cu}_{2} \mathrm{~V}_{2} \mathrm{O}_{7}\right.$, $\mathrm{CuV}_{2} \mathrm{O}_{6}, \mathrm{~V}_{2} \mathrm{O}_{5}, \mathrm{Fe}_{2} \mathrm{~V}_{4} \mathrm{O}_{13}, \mathrm{FeVO}_{4}$, H-type phase, L-type phase) and $\left(\mathrm{Cu}_{5} \mathrm{~V}_{2} \mathrm{O}_{10}, \mathrm{Cu}_{11} \mathrm{~V}_{6} \mathrm{O}_{26}, \mathrm{Cu}_{3} \mathrm{~V}_{2} \mathrm{O}_{8}, \mathrm{Cu}_{13} \mathrm{Fe}_{4}\right.$ $\left.\mathrm{V}_{10} \mathrm{O}_{44}\right)$. For establishing the phase relations in these areas ten additional mixtures of oxides were prepared. Their composition, heating conditions, and XRD analysis results after their last heating stage are shown in Table 3. Based on the presented results, the existence of eight another subsidiary subsystems can be stated. However, in no sample the compound $\mathrm{Fe}_{2} \mathrm{~V}_{4} \mathrm{O}_{13}$ was identified. The presence of this vanadate can be expected in the samples 33 and 34. On the other hand, it is known that the synthesis of pure $\mathrm{Fe}_{2} \mathrm{~V}_{4} \mathrm{O}_{13}$ by solid-state reaction is difficult and requires prolonged calcination [4]. Owing to these facts, to check which phases coexist at equilibrium in the polygon labeled by the phases: $\left(\mathrm{V}_{2} \mathrm{O}_{5}, \mathrm{Fe}_{2} \mathrm{~V}_{4} \mathrm{O}_{13}, \mathrm{FeVO}_{4}\right.$, H-type phase), some additional verifying investigations were performed. Two mixtures of ready-made phases were prepared with their composition corresponding to the samples 33 and 34. Sample 1 had a composition: $50.00 \mathrm{~mol} \%$ $\mathrm{V}_{2} \mathrm{O}_{5}, 33.33 \mathrm{~mol} \% \mathrm{Fe}_{2} \mathrm{~V}_{4} \mathrm{O}_{13}, 16.67 \mathrm{~mol} \% \mathrm{H}$-type phase $\left(\mathrm{Cu}_{3+1.5 x} \mathrm{Fe}_{4-x} \mathrm{~V}_{6} \mathrm{O}_{24}\right.$ with $\left.x=-0.333\right)$. The composition of sample 2 was as follows: $25.00 \mathrm{~mol} \% \mathrm{Fe}_{2} \mathrm{~V}_{4} \mathrm{O}_{13}$, $60.00 \mathrm{~mol} \% \mathrm{FeVO}_{4}, 15 \mathrm{~mol} \% \mathrm{H}$-type phase $\left(\mathrm{Cu}_{3+1.5 x} \mathrm{Fe}_{4-}\right.$ ${ }_{x} \mathrm{~V}_{6} \mathrm{O}_{24}$ with $\left.x=-0.333\right)$. Their compositions correspond to subsidiary subsystems: $\left(\mathrm{V}_{2} \mathrm{O}_{5}-\mathrm{Fe}_{2} \mathrm{~V}_{4} \mathrm{O}_{13}-\mathrm{H}\right.$-type phase $)$ and $\left(\mathrm{Fe}_{2} \mathrm{~V}_{4} \mathrm{O}_{13}-\mathrm{FeVO}_{4}-\mathrm{H}\right.$-type phase), respectively that can be expected based on the law of neighbouring phase regions. These mixtures were heated in four 20-h stages at $560{ }^{\circ} \mathrm{C}$ (several dozen of degrees celsius lower than their melting temperatures). The contents of both samples have been changed already after the first heating stage. Additional compounds were identified: $\mathrm{FeVO}_{4}$ (in the sample 1) and $\mathrm{V}_{2} \mathrm{O}_{5}$ (in the sample 2), whereas the content of $\mathrm{Fe}_{2} \mathrm{~V}_{4} \mathrm{O}_{13}$ distinctly decreased. After the last heating stage the composition of both samples was the same-they contained: $\mathrm{FeVO}_{4}$, H-type phase, and $\mathrm{V}_{2} \mathrm{O}_{5}$. These results have proved that the samples 33 and 34 after their last heating stage have attained the state of equilibrium. They have also shown that in the experiment conditions $\mathrm{Fe}_{2} \mathrm{~V}_{4} \mathrm{O}_{13}$ does not coexist at equilibrium with any phase forming in the system $\mathrm{CuO}-\mathrm{V}_{2} \mathrm{O}_{5}-\mathrm{Fe}_{2} \mathrm{O}_{3}$. It is known from the literature that also vanadate $\mathrm{Cr}_{2} \mathrm{~V}_{4} \mathrm{O}_{13}$ does not coexist at equilibrium with any phase forming in the analogous ternary system $\mathrm{ZnO}-\mathrm{V}_{2} \mathrm{O}_{5}-\mathrm{Cr}_{2} \mathrm{O}_{3}$ [28].

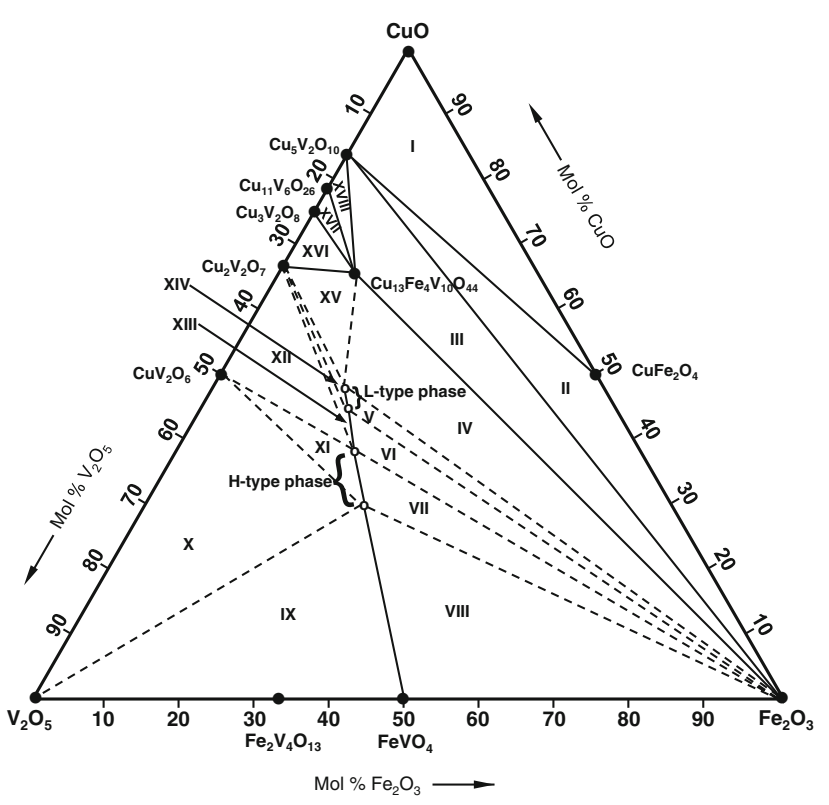

Fig. 5 Projection of solidus surface onto the plane of component concentration triangle of the $\mathrm{CuO}-\mathrm{V}_{2} \mathrm{O}_{5}-\mathrm{Fe}_{2} \mathrm{O}_{3}$ system 
Table 4 Melting temperatures of mixtures of phases coexisting at equilibrium

\begin{tabular}{|c|c|c|}
\hline No. & Subsystem & $\begin{array}{l}\text { Melting temperature/ } \\
{ }^{\circ} \mathrm{C}\end{array}$ \\
\hline I & $\mathrm{Cu}_{5} \mathrm{~V}_{2} \mathrm{O}_{10}, \mathrm{CuFe}_{2} \mathrm{O}_{4}, \mathrm{CuO}$ & $805 \pm 5$ \\
\hline II & $\mathrm{Cu}_{5} \mathrm{~V}_{2} \mathrm{O}_{10}, \mathrm{CuFe}_{2} \mathrm{O}_{4}, \mathrm{Fe}_{2} \mathrm{O}_{3}$ & $790 \pm 5$ \\
\hline III & $\mathrm{Cu}_{5} \mathrm{~V}_{2} \mathrm{O}_{10}, \mathrm{Fe}_{2} \mathrm{O}_{3}, \mathrm{Cu}_{13} \mathrm{Fe}_{4} \mathrm{~V}_{10} \mathrm{O}_{44}$ & $785 \pm 5$ \\
\hline IV & $\mathrm{Fe}_{2} \mathrm{O}_{3}, \mathrm{Cu}_{13} \mathrm{Fe}_{4} \mathrm{~V}_{10} \mathrm{O}_{44}$, L-type phase & $780 \pm 5$ \\
\hline $\mathrm{V}$ & $\mathrm{Fe}_{2} \mathrm{O}_{3}$, L-type phase & $800 \pm 5$ \\
\hline VI & $\mathrm{Fe}_{2} \mathrm{O}_{3}$, L-type phase, H-type phase & $795 \pm 5$ \\
\hline VII & $\mathrm{Fe}_{2} \mathrm{O}_{3}, \mathrm{H}$-type phase & $800 \pm 5$ \\
\hline VIII & $\mathrm{Fe}_{2} \mathrm{O}_{3}$, H-type phase, $\mathrm{FeVO}_{4}$ & $800 \pm 5$ \\
\hline IX & H-type phase, $\mathrm{V}_{2} \mathrm{O}_{5}, \mathrm{FeVO}_{4}$ & $635 \pm 5$ \\
\hline $\mathrm{X}$ & $\mathrm{H}$-type phase, $\mathrm{CuV}_{2} \mathrm{O}_{6}, \mathrm{~V}_{2} \mathrm{O}_{5}$ & $635 \pm 5$ \\
\hline $\mathrm{XI}$ & H-type phase, $\mathrm{CuV}_{2} \mathrm{O}_{6}$ & $650 \pm 5$ \\
\hline XII & H-type phase, $\mathrm{CuV}_{2} \mathrm{O}_{6}, \mathrm{Cu}_{2} \mathrm{~V}_{2} \mathrm{O}_{7}$ & $650 \pm 5$ \\
\hline XIII & $\begin{array}{l}\text { H-type phase, L-type phase, } \\
\mathrm{Cu}_{2} \mathrm{~V}_{2} \mathrm{O}_{7}\end{array}$ & $760 \pm 5$ \\
\hline XIV & L-type phase, $\mathrm{Cu}_{2} \mathrm{~V}_{2} \mathrm{O}_{7}$ & $760 \pm 5$ \\
\hline $\mathrm{XV}$ & $\begin{array}{l}\text { L-type phase, } \mathrm{Cu}_{2} \mathrm{~V}_{2} \mathrm{O}_{7} \text {, } \\
\qquad \mathrm{Cu}_{13} \mathrm{Fe}_{4} \mathrm{~V}_{10} \mathrm{O}_{44}\end{array}$ & $760 \pm 5$ \\
\hline XVI & $\mathrm{Cu}_{2} \mathrm{~V}_{2} \mathrm{O}_{7}, \mathrm{Cu}_{13} \mathrm{Fe}_{4} \mathrm{~V}_{10} \mathrm{O}_{44}, \mathrm{Cu}_{3} \mathrm{~V}_{2} \mathrm{O}_{8}$ & $760 \pm 5$ \\
\hline XVII & $\begin{array}{c}\mathrm{Cu}_{3} \mathrm{~V}_{2} \mathrm{O}_{8}, \mathrm{Cu}_{11} \mathrm{~V}_{6} \mathrm{O}_{26} \\
\mathrm{Cu}_{13} \mathrm{Fe}_{4} \mathrm{~V}_{10} \mathrm{O}_{44}\end{array}$ & $760 \pm 5$ \\
\hline XVIII & $\begin{array}{l}\mathrm{Cu}_{11} \mathrm{~V}_{6} \mathrm{O}_{26}, \mathrm{Cu}_{13} \mathrm{Fe}_{4} \mathrm{~V}_{10} \mathrm{O}_{44} \\
\mathrm{Cu}_{5} \mathrm{~V}_{2} \mathrm{O}_{10}\end{array}$ & $770 \pm 5$ \\
\hline
\end{tabular}

On the ground of all presented results a phase diagram of the system $\mathrm{CuO}-\mathrm{V}_{2} \mathrm{O}_{5}-\mathrm{Fe}_{2} \mathrm{O}_{3}$ in subsolidus area was worked out. Figure 5 shows a projection of the solidus surface onto the plane of the component concentration triangle of the system under study. The lines linking the $\mathrm{H}$ - and L-type phases with other compounds are drawn with a dashed line. As "O" were marked the positions of the samples 3, 7, 9, and 12, which are not monophase. The presented diagram indicates that in the $\mathrm{CuO}-\mathrm{V}_{2} \mathrm{O}_{5}-\mathrm{Fe}_{2} \mathrm{O}_{3}$ system no phase other than the known is formed. In this system, 18 subsidiary subsystems can be distinguished. In four of them two solid phases coexist at equilibrium, whereas the remaining 14 subsystems each have three solid phases coexisting at equilibrium. The melting temperatures of mixtures of phases coexisting at equilibrium in given areas are presented in Table 4.

\section{Conclusions}

Three phases involving all the components of the system $\mathrm{CuO}-\mathrm{V}_{2} \mathrm{O}_{5}-\mathrm{Fe}_{2} \mathrm{O}_{3}$ are formed: $\mathrm{Cu}_{13} \mathrm{Fe}_{4} \mathrm{~V}_{10} \mathrm{O}_{44}$, the phase with howardevansite-type structure and the phase with lyonsite-type structure. The H-type phase has the homogeneity range with the formula $\mathrm{Cu}_{3+1.5 x} \mathrm{Fe}_{4-x} \mathrm{~V}_{6} \mathrm{O}_{24}$ $(-0.5<x<0.041)$. It melts incongruently depositing $\mathrm{Fe}_{2} \mathrm{O}_{3}$ at the temperature range $820-800 \pm 5{ }^{\circ} \mathrm{C}$, depending on its composition. The homogeneity range of the L-type phase can be described as $\mathrm{Cu}_{3+1.5 x} \mathrm{Fe}_{4-x} \mathrm{~V}_{6} \mathrm{O}_{24}$ $(0.551<x<0.778)$. This phase also melts incongruently depositing $\mathrm{Fe}_{2} \mathrm{O}_{3}$, at $800 \pm 5{ }^{\circ} \mathrm{C}$. In the ternary system $\mathrm{CuO}-\mathrm{V}_{2} \mathrm{O}_{5}-\mathrm{Fe}_{2} \mathrm{O}_{3} 18$ subsidiary subsystems can be distinguished. In four of them two solid phases coexist at equilibrium, whereas the remaining 14 subsystems are triphase.

Open Access This article is distributed under the terms of the Creative Commons Attribution License which permits any use, distribution, and reproduction in any medium, provided the original author(s) and the source are credited.

\section{References}

1. Tanarungsun G, Kiatkittipong W, Praserthdam P, Yamada H, Tagawa T, Assabumrungrat S. Ternary metal oxide catalysts for selective oxidation of benzene to phenol. J Ind Eng Chem. 2008;14:596-601.

2. Dias APS, Dimitrov LD, Oliveira MC-R, Zavoianu R, Fernandes A, Portela MF. Oxidative dehydrogenation of butane over substoichiometric magnesium vanadate catalysts prepared by citrate route. J Non Cryst Solids. 2010;356:1488-97.

3. Häggblad R, Massa M, Andersson A. Stability and performance of supported $\mathrm{Fe}-\mathrm{V}$-oxide catalysts in methanol oxidation. J Catal. 2009;266:218-27.

4. Walczak J, Ziolkowski J, Kurzawa M, Osten-Sacken J, Lysio M. Studies on $\mathrm{Fe}_{2} \mathrm{O}_{3}-\mathrm{V}_{2} \mathrm{O}_{5}$ system. Pol J Chem. 1985;59:255-62.

5. Dabrowska G, Filipek E. Reactivity of the oxides in the ternary $\mathrm{V}_{2} \mathrm{O}_{5}-\mathrm{CuO}-\alpha-\mathrm{Sb}_{2} \mathrm{O}_{4}$ system in air. $\mathrm{J}$ Therm Anal Calorim. 2008;93:839-45.

6. Yang LT, Liang JK, Song GB, Chang H, Rao GH. Compounds and phase relations in the $\mathrm{SrO}-\mathrm{Fe}_{2} \mathrm{O}_{3}-\mathrm{CuO}, \mathrm{SrO}-\mathrm{Fe}_{2} \mathrm{O}_{3}-\mathrm{Gd}_{2} \mathrm{O}_{3}$ and $\mathrm{Gd}_{2} \mathrm{O}_{3}-\mathrm{Fe}_{2} \mathrm{O}_{3}-\mathrm{CuO}$ ternary systems. J Alloys Compd. 2003;353:301-6.

7. Blonska-Tabero A. The synthesis and some properties of new compound $\mathrm{Cu}_{13} \mathrm{Fe}_{4} \mathrm{~V}_{10} \mathrm{O}_{44}$. J Therm Anal Calorim. 2011. doi: 10.1007/s10973-011-2082-8.

8. Hughes JM, Starkey SJ, Malinconico ML, Malinconico LL. Lyonsite, $\mathrm{Cu}_{3}^{2+} \mathrm{Fe}_{4}{ }^{3+}\left(\mathrm{VO}_{4}\right)_{6}^{3-}$, a new fumarolic sublimate from Izalco volcano, El Salvador: descriptive mineralogy and crystal structure. Am Miner. 1987;72:1000-5.

9. Hughes JM, Drexler JW, Campana CF, Malinconico ML. Howardevansite, $\mathrm{NaCu}^{2+} \mathrm{Fe}_{2}{ }^{3+}\left(\mathrm{VO}_{4}\right)_{3}^{3-}$, a new fumarolic sublimate from Izalco volcano, El Salvador: descriptive mineralogy and crystal structure. Am Miner. 1988;73:181-6.

10. Lafontaine MA, Grenéche JM, Laligant T, Férey G. $\beta-\mathrm{Cu}_{3} \mathrm{Fe}_{4}\left(\mathrm{VO}_{4}\right)_{6}$ : structural study and relationships; physical properties. J Solid State Chem. 1994;108:1-10.

11. Wieczorek-Ciurowa K, Rakoczy J, Blonska-Tabero A, Filipek E, Niziol J, Dulian P. Mechanochemical synthesis of double vanadate in $\mathrm{Cu}-\mathrm{Fe}-\mathrm{V}-\mathrm{O}$ system and its physicochemical and catalytic properties. Catal Today. 2011;176:314-7.

12. Patoux S, Richardson TJ. Lithium insertion chemistry of some iron vanadates. Electrochem Commun. 2007;9:485-91.

13. Belik AA, Malakho AP, Pokholok KV, Lazoryak BI. Phase formation in $\mathrm{Cu}_{3+1.5 x} \mathrm{R}_{4-x}\left(\mathrm{VO}_{4}\right)_{6}(\mathrm{R}=\mathrm{Fe}$ and $\mathrm{Cr})$ systems: crystal 
structure of $\mathrm{Cu}_{2.5} \mathrm{Fe}_{4.333}\left(\mathrm{VO}_{4}\right)_{6}, \quad \mathrm{Cu}_{4} \mathrm{Fe}_{3.333}\left(\mathrm{VO}_{4}\right)_{6}, \quad$ and $\mathrm{Cu}_{4.05} \mathrm{Cr}_{3.3}\left(\mathrm{VO}_{4}\right)_{6}$. J Solid State Chem. 2001;56:339-48.

14. Pless JD, Bardin BB, Kim H-S, Ko D, Smith MT, Hammond RR, Stair PC, Poeppelmeier KR. Catalytic oxidative dehydrogenation of propane over $\mathrm{Mg}-\mathrm{V} / \mathrm{Mo}$ oxides. J Catal. 2004;223:419-31.

15. Blonska-Tabero A. A new iron lead vanadate $\mathrm{Pb}_{2} \mathrm{FeV}_{3} \mathrm{O}_{11}$ : synthesis and some properties. Mater Res Bull. 2009;44:1621-5.

16. Blonska-Tabero A, Bosacka M, Dabrowska G, Filipek E, Piz M, Rychlowska-Himmel I, Tabero P, Tomaszewicz E. The synthesis and properties of the phases obtained by solid-solid reactions. J Min Metall. 2008;44B:19-26.

17. Bělina P, Myšková V, Šulcová P. Comparison of the crystallization and solid state reaction methods for the preparation of rareearth orthophosphates. J Therm Anal Calorim. 2009;96:949-954.

18. Tabero P. Formation and properties of the new $\mathrm{Al}_{8} \mathrm{~V}_{10} \mathrm{~W}_{16} \mathrm{O}_{85}$ and $\mathrm{Fe}_{8-x} \mathrm{Al}_{x} \mathrm{~V}_{10} \mathrm{~W}_{16} \mathrm{O}_{85}$ phases with the $\mathrm{M}-\mathrm{Nb}_{2} \mathrm{O}_{5}$ structure. J Therm Anal Calorim. 2010;101:561-6.

19. Filipek E, Piz M. The reactivity of $\mathrm{SbVO}_{5}$ with $\mathrm{T}-\mathrm{Nb}_{2} \mathrm{O}_{5}$ in solid state in air. J Therm Anal Calorim. 2010;101:447-53.

20. Sulcová P, Vitásková L, Trojan M. Thermal analysis of the $\mathrm{Ce}_{1-x} \mathrm{~Tb}_{x} \mathrm{O}_{2}$ pigments. J Therm Anal Calorim. 2010;99:409-13.
21. Kurzawa M, Blonska-Tabero A. The synthesis and selected properties of new compounds: $\mathrm{Mg}_{3} \mathrm{Fe}_{4}\left(\mathrm{VO}_{4}\right)_{6}$ and $\mathrm{Zn}_{3} \mathrm{Fe}_{4}\left(\mathrm{VO}_{4}\right)_{6}$. Mater Res Bull. 2002;37:849-58.

22. Blonska-Tabero A. New phase in the system $\mathrm{FeVO}_{4}-\mathrm{Cd}_{4} \mathrm{~V}_{2} \mathrm{O}_{9}$. J Therm Anal Calorim. 2008;93:707-10.

23. Lavat AE, Grasselli MC, Baran EJ. The IR spectra of the $\left(\mathrm{Cr}_{x} \mathrm{Fe}_{1-x}\right) \mathrm{VO}_{4}$ phases. J Solid State Chem. 1989;78:206-8.

24. Dabrowska G, Tabero P, Kurzawa $M$. Phase relations in the $\mathrm{Al}_{2} \mathrm{O}_{3}-\mathrm{V}_{2} \mathrm{O}_{5}-\mathrm{MoO}_{3}$ system in the solid state. The crystal structure of $\mathrm{AlVO}_{4}$. J Phase Equilib Diffus. 2009;30:220-9.

25. Zhuravlev VD, Velikodnyi YA, Kristallov LV. Issledovanie fazovykh ravnovesii v sisteme $\mathrm{CuO}-\mathrm{SrO}-\mathrm{V}_{2} \mathrm{O}_{5}$. Zh Neorg Khim. 1987;32:3060-3.

26. McDevitt NT, Baun WL. Infrared absorption study of metal oxides in the low frequency region $\left(700-240 \mathrm{~cm}^{-1}\right)$. Spectrochim Acta. 1964;20:799-808.

27. Blonska-Tabero A, Kurzawa M. Phase formation in the $\mathrm{FeVO}_{4}$ $\mathrm{Co}_{3} \mathrm{~V}_{2} \mathrm{O}_{8}$ system. J Therm Anal Calorim. 2007;88:33-6.

28. Rychlowska-Himmel I, Bosacka M. Phase equilibria in the subsolidus area in the $\mathrm{ZnO}-\mathrm{Cr}_{2} \mathrm{O}_{3}-\mathrm{V}_{2} \mathrm{O}_{5}$ system. Thermochim Acta. 2010;503-504:132-5. 